\title{
ANTISIPASI RISIKO KEBAKARAN MELALUI PELATIHAN PENGGUNAAN ALAT PEMADAM API PORTABLE
}

\author{
Waris Wibowo'), Wegig Pratama1), Ningrum Astriawati'), Prasetya Sigit Santosa1), Sahudiyono2) \\ 1)Program Studi Permesinan Kapal, Sekolah Tinggi Maritim Yogyakarta, Jl. Magelang Km 4.4, Yogyakarta, Indonesia \\ 2)Program Studi Managemen Transportasi Laut, Sekolah Tinggi Maritim Yogyakarta, Jl. Magelang Km 4.4, Yogyakarta, \\ Indonesia
}

Corresponding author : Ningrum Astriawati

E-mail : waris.amy68@gmail.com

\section{Diterima 10 April 2021, Disetujui 15 April 2021}

\begin{abstract}
ABSTRAK
Tujuan dari pengabdian ini adalah untuk meningkatkan pengetahuan dan keterampilan masyarakat dalam penanggulangan risiko kebakaran di daerah pemukiman padat penduduk melalui pelatihan penggunaan alat pemadam api portable. Pengabdian ini dilaksanakan di Desa Nogotirto, Gamping, Sleman. Peserta Pelatihan ini berjumlah 20 orang. Kegiatan pengabdian masyarakat dilaksanakan melalui 5 tahap, yaitu (1) Pelaksanaan pretest; (2) Pemberian materi melalui metode ceramah dan tanya jawab; (3) Demonstrasi penggunaan alat pemadam api portable; (4) Praktik individu menggunakan alat pemadam api portable; (5) Pelaksanaan Posttest. Capaian peningkatan pengetahuan dan keterampilan masyarakat diukur menggunakan kuesioner pretest dan posttest, data diolah dan diuji dengan uji paired $T$-test. Adapun hasil dari pengabdian ini adalah adanya peningkatan pengetahuan dan keterampilan masyarakat dalam penanggulangan risiko kebakaran, disamping itu adanya perbedaan rata-rata tingkat pengetahuan dan keterampilan penanggulangan kebakaran sebelum dan setelah pelaksanaan kegiatan pelatihan.
\end{abstract}

Kata kunci: kebakaran; pelatihan; pemadam api; portable

\begin{abstract}
This service aims to increase the knowledge and skills of the community in managing fire risks in densely populated residential areas through training in the use of portable fire extinguishers. This service was carried out in Nogotirto Village, Gamping, Sleman. The number of participants in this training is 20 people. Community service activities are carried out in 5 stages, namely (1) Pretest implementation; (2) Providing material using the method of lecture and question and answer; (3) Demonstration of the use of portable fire extinguishers; (4) Individual practice using portable fire extinguishers; (5) Implementation of Posttest. The achievement of increasing the knowledge and skills of the community was measured using a pretest and posttest questionnaire, the data was processed and tested using the paired T-test. The result of this service is an increase in the knowledge and skills of the community in managing fire risk in densely populated residential areas, in addition to that, there is a difference in the average level of knowledge and skills in fire management before and after the implementation of training activities.
\end{abstract}

Keywords: fire; training; fire extinguisher; portable

\section{PENDAHULUAN}

Nogotirto merupakan perkampungan yang terletak di kecamatan Gamping, Sleman Yogyakarta yang padat hunian dan penduduk, hal ini sangat rentan terhadap bencana baik yang disebabkan oleh alam, non alam, maupun manusia. Kita menyadari bahwa dampak dari bencana dapat mengakibatkan timbulnya korban jiwa, kerusakan lingkungan, kerugian harta benda, dan efek psikologis masyarakat(SP, 2005). Melihat dampak yang ditimbulkan dari bencana maka keterlibatan masyarakat, lembaga-lembaga non pemerintah dan peran dari pemerintah sangat dibutuhkan, untuk meminimalisir terjadinya bencana tersebut, hal ini sejalan dengan Peraturan Gubernur DIY No. 70 tahun 2014 tentang keterlibatan masyarakat dalam penyelenggaraan penanggulangan bencana. Pasal 4 disebutkan sebagai berikut: (1) Masyarakat perlu terlibat aktif dalam setiap penyelenggaraan penanggulangan bencana sesuai dengan kapasitas yang dimiliki. (2) Setiap lembaga/organisasi yang menyelenggarakan penanggulangan bencana harus melibatkan masyarakat lokal. (3) Apabila tidak ada kegiatan penyelenggaraan penanggulangan bencana oleh pihak pemerintah dan pemerintah daerah, lembaga non pemerintah dan swasta, maka masyarakat 
perlu berinisiatif sendiri untuk melakukan kegiatan penanggulangan bencana sesuai dengan kapasitas yang dimiliki. (4) Dalam penyelenggaraan penanggulangan bencana, masyarakat harus koordinasi dengan pihak pemerintah daerah dan atau pemerintah setempat dan perlu membangun jaringan dan dukungan dari pihak lain, dan dikuatkan dengan Peraturan Pemerintah Republik Indonesia Nomor $21 \quad$ Tahun 2008 Tentang Penyelenggaraan Penanggulangan Bencana.

Kebakaran adalah satu bentuk bencana yang diakibatkan dari ulah manusia/ alam/ non alam yang bisa terjadi di wilayah Nogotirto yang padat dengan pemukiman, untuk itu masyarakatnya seyogyanya dibekali keahlian untuk mengantisipasi terjadinya bencana/ menangani apabila terjadi bencana kebakaran(Patuju, 2018). Keahlian masyarakat untuk dapat mengantisipasi dan menanggulangi bencana kebakaran dapat dilakukan melalui kegaitan program pelatihan yang intensif dari para ahli pada bidang tersebut(Irawan, 2019).

Sekolah Tinggi Maritim Yogyakarta (STIMARYO), merupakan satu-satunya perguruan tinggi bidang pelayaran yang berada di wilayah Yogyakarta yang memiliki komitmen peduli terhadap masyarakat khususnya wilayah Yogyakarta dalam menyelesaikan permasalahan-permasalahan yang terjadi. Berkaitan dengan penanggulangan bencana kebakaran STIMARYO memiliki Sumberdaya Manusia (SDM) yang memadai dan fasilitas Alat Pemadam Api portable modern (APAR) yang lengkap untuk kegiatan pelatihan. STIMARYO bekerjasama dengan Kementerian Pekerjaan Umum dan Perumahan Rakyat, Direktorat Pengembangan Kawasan Pemukiman DIY melaksanakan kegiatan pelatihan dalam menangani kebakaran, sebagai bentuk pengabdian kepada masyarakat, sehingga diharapkan dapat meningkatkan pengetahuan/ pemahaman dan keterampilan dalam penanganan kebakaran.

\section{METODE}

Metode yang digunakan dalam kegiatan Pengabdian Kepada Masyarakat (PKM) mengenai antisipasi risiko kebakaran melalui pelatihan penggunaan alat pemadam api portable adalah metode ceramah dan tanya jawab, metode demonstrasi dan metode praktik langsung (Utama \& Dewi, 2020). PKM dilaksanakan di Desa Nogotirto, Gamping, Sleman. Ada lima (5) bentuk kegiatan yang dilaksanakan dalam program pelatihan penanggulangan kebakaran adalah sebagai berikut: 1. Pretest mengenai tingkat pengetahuan dan keterampilan mengenai antisipasi risiko kebakaran. 2. Pemberian materi dengan metode ceramah dan tanya jawab mengenai antisipasi risiko kebakaran dan pemberian materi terkait alat pemadam api portable 3. Demonstrasi penggunaan alat pemadam api portable. 4. Praktik individu menggunakan alat pemadam api portable 5 . Posttest tingkat pengetahuan dan keterampilan mengenai antisipasi risiko kebakaran. PKM ini dilaksanakan di Desa Nogotirto, Gamping, Sleman. Peserta Pelatihan ini berjumlah 20 orang. Dalam melakukan demonstrasi bertempat di lapangan desa Nogotirto.

\section{HASIL DAN PEMBAHASAN}

Tahap pertama kegiatan pengabdian dimulai dengan melakukan pretest mengenai tingkat pengetahuan dan keterampilan masyarakat Desa Nogotirto, Gamping, Sleman. Pertanyaan-pertanyaan terkait upaya penanggulangan kebakaran, untuk tingkat keterampilan dinilai pada saat praktik langsung penggunaan alat pemadam api portable baik dengan metode tradisional (alat pemadam api portable sederhana) maupun modern (APAR). Selanjutnya, pada tahap kedua dilakukan pemberian materi tantang penanggulangan risiko kebakaran. Materi disampaikan melalui bantuan slide powerpoint maupun video terkait proses penanggulangan kebakaran dengan metode tradisional maupun modern Seperti yang terlihat pada gambar 1 . Di akhir sesi pemberian materi, dibuka sesi diskusi dan tanya jawab antara pengabdi dan peserta pelatihan.

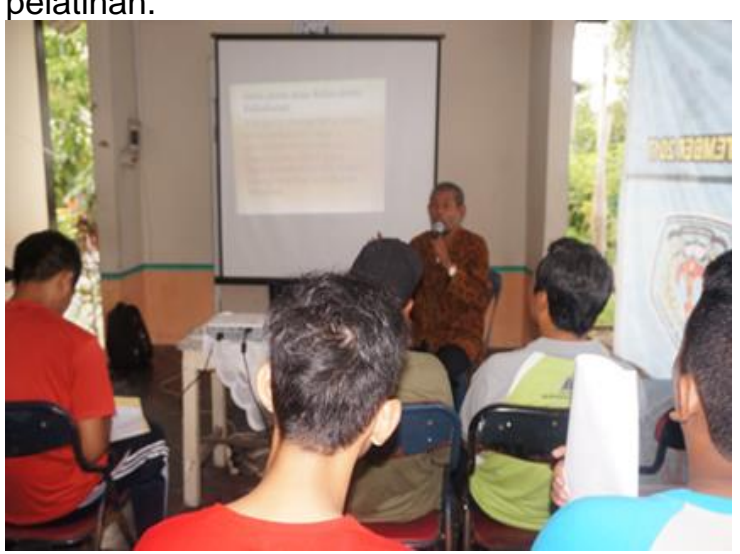

Gambar 1. Tim Pengabdi sedang mempresentasikan materi pelatihan

Tahap ketiga yaitu demonstrasi penggunaan alat pemadam api portable. Pemadaman api skala kecil yaitu menggunakan alat pemadam api portable sederhana yaitu kain basah, sedangkan pemadaman api dengan skala sedang menggunakan alat pemadam api portable modern yaitu APAR. Tim pengabdi sedang menjelaskan dan mendemonstrasikan alat pemadam api portable 
modern (APAR) seperti yang terlihat pada Gambar 2 berikut ini.

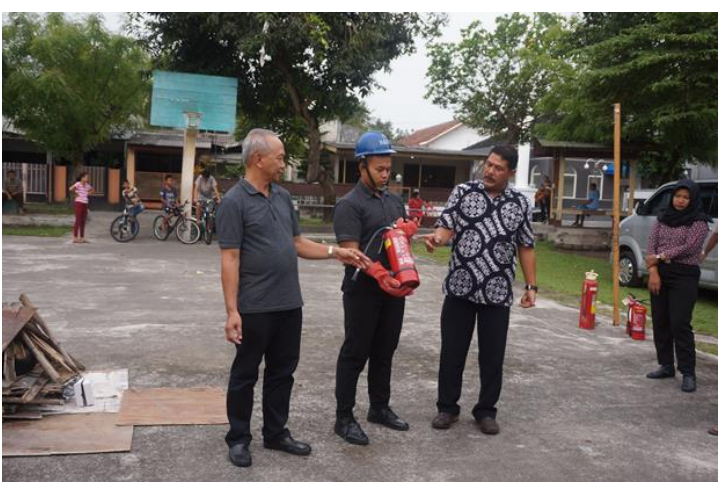

Gambar 2. Tim Pengabdi sedang menjelaskan dan mendemonstrasikan penggunaan APAR

Tahap keempat dari pengabdian ini adalah praktik individu menggunakan alat pemadam api portable. Dalam pelaksanaannya, peserta memadamkan api secara bergilir satu per satu, sehingga diharapkan terjadi peningkatan keterampilan pemadaman api pada masing-masing warga yang mengikuti pelatihan, seperti yang ditunjukkan pada Gambar 3 dan 4 berikut.

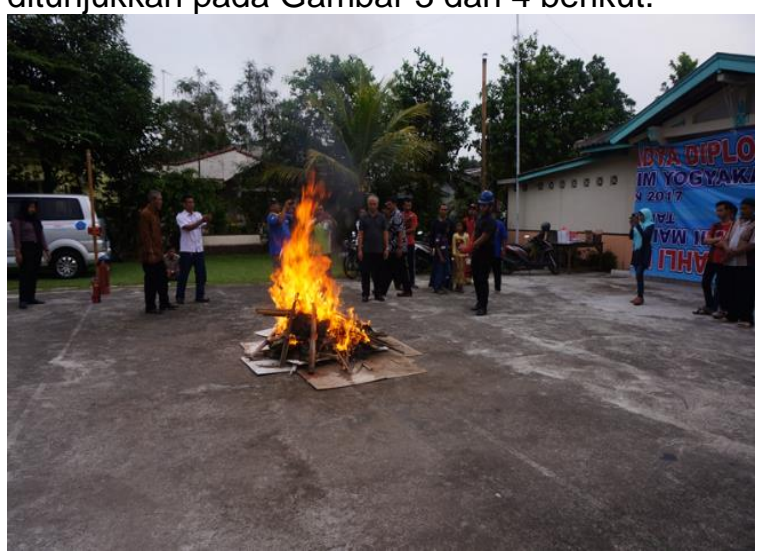

Gambar 3. Pembuatan Api untuk simulasi penggunaan APAR di Lapangan Desa

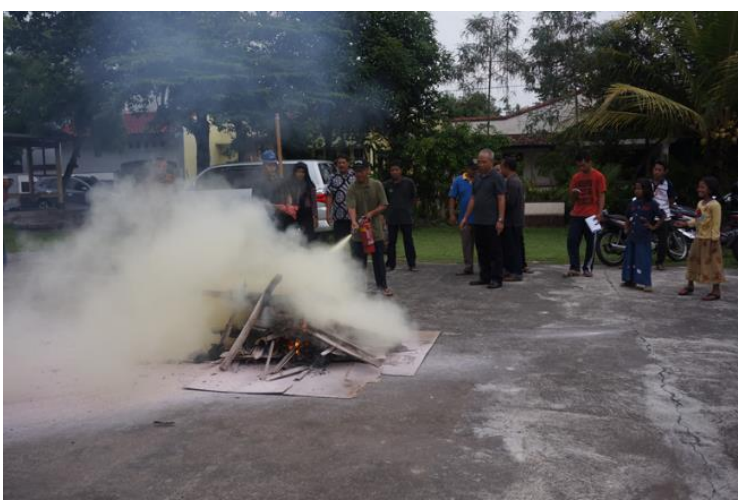

Gambar 4. Peserta pelatihan sedang melaksanakan praktik menggunakan APAR
Volume 4, Nomor 2., April 2021. p-ISSN : 2614-5251 e-ISSN : 2614-526X

Tahap kelima, dilakukan posttest untuk mengetahui peningkatan pengetahuan dan keterampilan masyarakat tentang penanggulangan kebakaran setelah pemberian materi, demonstrasi dan praktik. Soal-soal posttest sama dengan soal-soal yang diberikan pasa saat pretest. Berikut disajikan proporsi hasil pretest dan posttest tingkat pengetahuan masyarakat terhadap penanggulangan risiko kebakaran skala kecil dan sedang.

PROPORSI TINGKAT PENGETHHUN DAN KETERAMPIAN WARGA TENTANG RESIKO KEBAKARAN

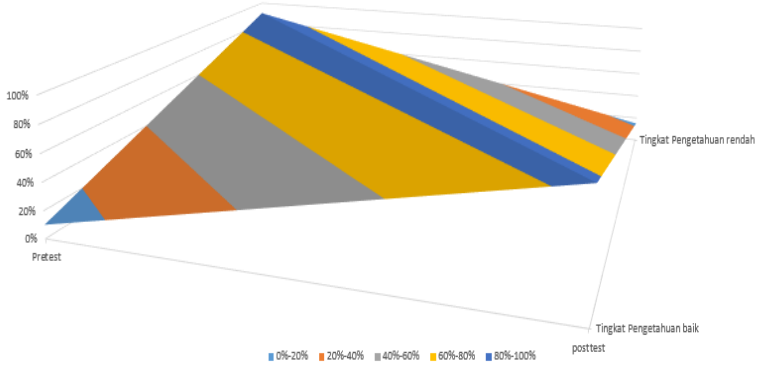

Gambar 5. Proporsi Tingkat pengetahuan dan keterampilan warga saat pretes dan posttest

Dari gambar 5 diatas diperoleh bahwa Proporsi tingkat pengetahuan dan keterampilan warga saat pretes dan posttest meningkat. Dari hasil pretest diperoleh bahwa tingkat pengetahuan dan keterampilan warga sebelum adanya pelatihan dengan kategori baik/ tinggi sebesar $10 \%$ dan kategori rendah sebesar $90 \%$. Pengetahuan dan keterampilan tersebut meningkat setelah pemberian materi, demonstrasi dan praktik, dengan hasil posttes diperoleh kategori baik/tinggi sebesar $85 \%$ dan rendah sebesar $15 \%$. Sehingga pengetahuan dan keterampilan warga mengalami peningkatan dengan kategori baik sebesar $75 \%$.

Selanjutnya dihitung adakah perbedaan yang signifikan antara pengetahuan dan keterampilan penanggulangan kebakaran sebelum dan setelah pelaksanaan kegiatan pelatihan melalui nilai pretest dan posttes yang sudah diberikan. Untuk mengetahui nilai signifikan tersebut pengabdi menggunakan uji paired T-test dengan aplikasi SPSS. Sebelum dilakukan uji paired T-test terlebih dahulu dilakukan Uji Normalitas menggunakan Shapiro-Wilk, karena jumlah data yang diambil sebanyak 20 peserta.Berikut hasil uji normalitas data pretest dan posttest dari peserta pelatihan. 
Tabel 1. Hasil Uji normalitas Tests of Normality

\begin{tabular}{|l|r|r|r|r|r|r|}
\hline \multirow{2}{*}{} & \multicolumn{3}{|c|}{ Kolmogorov-Smirnov $^{\text {a }}$} & \multicolumn{3}{c|}{ Shapiro-Wilk } \\
\cline { 2 - 7 } & Statistic & \multicolumn{1}{c|}{ df } & \multicolumn{1}{c|}{ Sig. } & Statistic & \multicolumn{1}{c|}{ df } & \multicolumn{1}{c|}{ Sig. } \\
\hline Pretest & .232 & 20 & .006 & .914 & 20 & .075 \\
Postest & .169 & 20 & .136 & .916 & 20 & .082 \\
\hline
\end{tabular}

a. Lilliefors Significance Correction

Seperti yang terlihat pada tabel 1 hasil uji normalitas untuk pretest memperoleh Nilai signifikansi ( $p$ ) pada uji Shapiro-Wilk adalah 0.8075 ( $p>0.05)$, sehingga berdasarkan uji normalitas Shapiro-Wilk data untuk pretest berdistribusi normal. hasil uji normalitas untuk data posttes memperoleh Nilai signifikansi (p) pada uji Shapiro-Wilk adalah 0.082 ( $p>0.05$ ), sehingga berdasarkan uji normalitas ShapiroWilk data untuk postest berdistribusi normal. Selanjutnya dilakukan uji paired T-test untuk mengetahui apakah ada perbedaan yang signifikan antara pengetahuan dan keterampilan penanggulangan kebakaran sebelum dan setelah pelaksanaan kegiatan pelatihan. Berikut disajikan hasil perhitungan uji paired T-test data pretest dan posttest dari peserta pelatihan.

Tabel 2. Hasil uji Paired sample statistics

Paired Samples Statistics

\begin{tabular}{|ll|c|r|r|c|}
\hline & & Mean & $\mathrm{N}$ & Std. Deviation & $\begin{array}{c}\text { Std. Error } \\
\text { Mean }\end{array}$ \\
\hline Pair 1 & Pretest & 40.5000 & 20 & 10.99043 & 2.45753 \\
& Postest & 72.5000 & 20 & 12.92692 & 2.89055 \\
\hline
\end{tabular}

dari tabel 2 diatas terlihat bahwa rata-rata hasil pretest 20 orang peserta pelatihan mendapatkan skor 40.5 dengan standar deviasi sebesar 10.99 dan setelah mendapatkan pelatihan rata-rata hasil posttest 20 orang peserta pelatihan mendapatkan skor 72.5 dengan standar deviasi sebesar 12.93 . Karena nilai rata-rata hasil pretest $40.5<$ hasil posttest 72.5 maka secara deskriptif ada perbedaan rata-rata peningkatan pengetahuan dan keterampilan masyarakat tentang penanggulangan kebakaran antara sebelum dengan setelah pemberian materi, demonstrasi dan praktik.

Tabel 3. Hasil uji Paired sample Correlations Paired Samples Correlations

\begin{tabular}{|c|c|c|c|c|}
\hline & & $\bar{N}$ & Correlation & Sig. \\
\hline Pair 1 & Pretest \& Postest & 20 & -.157 & 507 \\
\hline
\end{tabular}

Dari Output tabel 3 menunjukkan hasil uji korelasi / hubungan antara variabel pretest dengan variabel posttest. Berdasarkan output diperoleh bahwa nilai korelasi sebesar -0.157 dengan nilai signifikansi (sig.) sebesar 0.507 . Karena nilai sig. $0.507>$ nilai probabilitas 0.05 , maka dapat dikatakan bahwa tidak ada hubungan antara variabel pretest dengan variabel posttest. Selanjutnya disajikan data hasil paired samples test sebagai berikut.

Tabel 4. Hasil uji paired samples test

\begin{tabular}{|c|c|c|c|c|c|c|c|c|}
\hline \multicolumn{9}{|c|}{ Paired Samples Test } \\
\hline & \multicolumn{5}{|c|}{ Paired Differences } & \multirow[b]{3}{*}{$\mathrm{t}$} & \multirow[b]{3}{*}{ df } & \multirow[b]{3}{*}{ Sig. (2-tailed) } \\
\hline & \multirow[b]{2}{*}{ Mean } & \multirow[b]{2}{*}{ Std. Deviation } & \multirow{2}{*}{$\begin{array}{l}\text { Std. Error } \\
\text { Mean }\end{array}$} & \multicolumn{2}{|c|}{$\begin{array}{c}\text { 95\% Confidence Interval of the } \\
\text { Difference }\end{array}$} & & & \\
\hline & & & & Lower & Upper & & & \\
\hline Pair 1 Pretest-Postest & -32.00000 & 18.23819 & 4.07818 & -40.53574 & -23.46426 & -7.847 & 19 & .000 \\
\hline
\end{tabular}

Rumusan Hipotesis :

$\mathrm{H}_{0}=$ Tidak ada perbedaan rata-rata tingkat pengetahuan dan keterampilan penanggulangan kebakaran sebelum dan setelah pelaksanaan kegiatan pelatihan.

$\mathrm{H}_{\mathrm{a}}=$ Ada perbedaan rata-rata tingkat pengetahuan dan keterampilan penanggulangan kebakaran sebelum dan setelah pelaksanaan kegiatan pelatihan.

Menurut Santoso (2016) pedoman pengambilan keputusan dalam uji paired samples t-test berdasarkan nilai signifikansi (Sig.) hasil output SPSS sebagai berikut.

1. Jika nilai Sig (2-tailed) $<0.05$, maka $\mathrm{H}_{0}$ ditolak dan $\mathrm{H}_{\mathrm{a}}$ diterima

2. Jika nilai Sig (2-tailed) $>0.05$, maka $\mathrm{H}_{0}$ diterima dan $\mathrm{H}_{\mathrm{a}}$ ditolak
Berdasarkan Tabel 4 diatas diketahui bahwa nilai Sig (2-tailed) adalah sebesar 0.000 $<0.05$, maka maka $\mathrm{H}_{0}$ ditolak dan $\mathrm{H}_{\mathrm{a}}$ diterima. Sehingga dapat disimpulkan bahwa ada perbedaan rata-rata tingkat pengetahuan dan keterampilan penanggulangan kebakaran sebelum dan setelah pelaksanaan kegiatan pelatihan.

\section{SIMPULAN DAN SARAN}

Dari hasil pengabdian tentang antisipasi risiko kebakaran melalui pelatihan penggunaan alat pemadam api portable yang dilakukan oleh tim pengabdi dapat diambil kesimpulan bahwa terjadi peningkatan pengetahuan dan keterampilan masyarakat dalam penanggulangan risiko kebakaran di daerah pemukiman padat penduduk melalui pelatihan penggunaan alat pemadam api portable sebesar $75 \%$ dengan kategori baik. 
Disamping itu dari hasil hipotesis diperoleh adanya perbedaan rata-rata tingkat pengetahuan dan keterampilan penanggulangan kebakaran sebelum dan setelah pelaksanaan kegiatan pelatihan.

\section{UCAPAN TERIMAKASIH}

Pengabdian Kepada Masyarakat ini didanai oleh Lembaga Penelitian dan Pengabdian kepada Masyarakat Yogyakarta Sekolah Tinggi Maritim. Kami berterima kasih kepada masyarakat Desa Nogotirto, Gamping, Sleman yang telah ikut berpartisipasi demi suksesnya PKM ini.

\section{DAFTAR RUJUKAN}

Irawan, B. (2019). ANALISIS PARTISIPASI MASYARAKAT DALAM PELATIHAN SISTEM KETAHANAN KEBAKARAN LINGKUNGAN PADA KANTOR PENANGGULANGAN KEBAKARAN DAN PENYELAMATAN SEKTOR JOHAR BARU JAKARTA PUSAT. Jurnal Reformasi Administrasi: Jurnal IImiah Untuk Mewujudkan Masyarakat Madani, 6(1), 42-52.

Patuju, A. (2018). Hubungan Sikap Terhadap Resiko Bencana Kebakaran dengan Kesiapsiagaan Menghadapi Kebakaran di PemukimanKelurahan Air Putih Kecamatan Samarinda Ulu.

Peraturan Gubernur DIY No. 70 tahun 2014. (2014). TENTANG KETERLIBATAN MASYARAKAT DALAM PENYELENGGARAAN PENANGGULANGAN BENCANA.

PERATURAN PEMERINTAH REPUBLIK INDONESIA NOMOR 21 TAHUN 2008. (2008). PENYELENGGARAAN PENANGGULANGAN BENCANA.

Santoso, S. (2016). Panduan Lengkap SPSS Versi 23. Elex Media Komputindo.

SP, D. A. (2005). Bencana Alam, Bencana Teknologi, Racun Dan Polusi Udara: Sebuah Tinjauan Psikologi Lingkungan. Buletin Psikologi, 13(1), 18-37.

Utama, D. A., \& Dewi, S. R. (2020). PROGRAM PELATIHAN PERLINDUNGAN RISIKO KEBAKARAN DAERAH PEMUKIMAN PADAT PENDUDUK DI KOTA SAMARINDA. J-Dinamika: Jurnal Pengabdian Masyarakat, 5(1). 